\title{
The Question of Democracy and Dictatorship: Lenin's Critique of Kautsky the Renegade
}

Lenin first accused Kautsky of being a renegade of Marxism after the Russian Revolution. Until then, Lenin, like many others, had regarded Kautsky as a real and genuine Marxist. The best-known and most vehement criticism of Kautsky was first introduced by Lenin after Kautsky's direct and unconditional critique of the Russian Revolution and Lenin's conception of the dictatorship of the proletariat. Lenin's critique reached its utmost forcefulness after the publication of Kautsky's The Dictatorship of the Proletariat in 1918. Kautsky had become a 'renegade of Marxism'. In The Proletarian Revolution and the Renegade Kautsky, ${ }^{1}$ Lenin criticised Kautsky's conception of democracy and the dictatorship of the proletariat.

The socialist character of the Russian Revolution and the dictatorship of the proletariat were the main targets in Kautsky's The Dictatorship of the Proletariat. The relation between dictatorship and democracy was understood both by Lenin and by Kautsky to be the leading question. ${ }^{2}$ The analysis of these two methods of government was the main idea in Kautsky's pamphlet. Kautsky's interpretation of Marx's concept of the dictatorship of the proletariat was, in Lenin's opinion, totally false, even though Kautsky tried to defend his own position as a genuine Marxist interpreter by claiming that Marx understood the dictatorship of the proletariat not as a form of government, but rather as a specific state of affairs or condition, a mediating state between a bourgeois and real proletarian government. ${ }^{3}$ Lenin thought that Kautsky's attempt was ridiculous. His main mistake was that he did not make any distinction between democracy in general and bourgeois democracy in particular; he did not even pose the question about the class character of bourgeois democracy. According to Lenin, democracy always functions in favour of one particular class. ${ }^{4}$

In Lenin's view, Kautsky understood only one question correctly: dictatorship means that one class in society is deprived of its political rights, and during proletarian dictatorship this class is the bourgeoisie. Kautsky was, however, at

1 Lenin 1967g; cf. also Trotsky 1921.

2 Lenin 1967g, p. 45.

3 Lenin 1967g, pp. 47-8, 50 .

4 Lenin 1967g, p. 46. 
the same time mistaken in claiming that proletarian dictatorship is equivalent to a dictatorship exercised by a small group of persons depriving the rest of society of its democratic rights. The dictatorship of the proletariat is, on the contrary, equal to the most perfect democracy of the working class and other poor elements in society. Revolutionary proletarian dictatorship is equal to power which has been won in class struggle and which is maintained and exercised even violently against the bourgeoisie. It is a power not bound by any laws. ${ }^{5}$

According to Lenin, the whole idea of Kautsky's discussion of democracy and dictatorship seemed to rest on an attempt to conceal the essential difference between a violent and a peaceful transition to socialism. Kautsky opposed any use of violence in revolution:

Kautsky has in a most unparalleled manner distorted the concept of dictatorship of the proletariat, and has turned Marx into a common liberal; that is, he himself has sunk to the level of a liberal who utters banal phrases about 'pure democracy', embellishing and glossing over the class content of bourgeois democracy, and shrinking, above all, from the use of revolutionary violence by the oppressed class. By so 'interpreting' the concept 'revolutionary dictatorship of the proletariat' as to expunge the revolutionary violence of the oppressed class against its oppressors, Kautsky has beaten the world record in the liberal distortion of Marx. The renegade Bernstein has proved to be a mere puppy compared with the renegade Kautsky. ${ }^{6}$

Lenin never tired of repeating the claim that proletarian democracy is a million times more democratic than any form of bourgeois democracy. This essential fact was misunderstood by Kautsky because he never faced the question of the class character of democracy, a question separating a real Marxist from a liberal trying to pose as a Marxist. Soviet Russia is the most democratic country in the world, its workers and proletarian peasants have the right to make use of the freedom of assembly, the freedom of press and the right to elect their own representatives in state institutions, and these rights are not only formal rights - as in a bourgeois democracy. The material conditions for their realisation are present in Soviet Russia. ${ }^{7}$ This simple fact should prove that

\footnotetext{
5 Lenin 1967g, p. $5^{2}$.

6 Lenin 1967g, p. 54 .

7 Lenin 1967g, pp. $5^{8-9}$.
} 
a soviet democracy really is a democracy for the poor and in this sense crucially differs from any formal democracy which only makes it possible for the rich to use the democratic institutions in their own interests.

Kautsky did not think it possible for the soviets to become a new representative state institution, even though he accepted their role as oganisers and agitators of the working class. In Lenin's opinion, however, Kautsky's position was strange. He acknowledged that the proletariat has a right to wage war against capital which is repressing and subordinating it and the whole nation. On the other hand, he did not approve of the ideal proletarian institutions, the soviets, becoming a real state power. Kautsky's position was thus one of a petit bourgeois afraid of class struggle and its logical conclusion, namely, a socialist state power. ${ }^{8}$

Lenin's critique of Kautsky could be summarised as follows: Kautsky did not understand the nature of the dictatorship of the proletariat in general and its Russian variant in particular. In demanding the maintenance and introduction of democratic institutions in their bourgeois form, Kautsky revealed that he did not understand that democracy is always equivalent to the exercise of the power of one class over another, and that the dictatorship of the proletariat is in reality the most democratic form of exercising state power; it is true that capitalists and the big agrarian proprietors are deprived of their democratic rights. The political rights of workers and poor peasants are in fact more comprehensive than ever. Despite his critique, Lenin did not, in principle, deny the possibility of establishing socialism without depriving the bourgeoisie of their former democratic rights - even though he thought of it more as an exception. In certain developed countries with long traditions of political freedom and democracy, parliamentary democracy could be maintained even during the transitionary period, which, under these circumstances, would be more peaceful. ${ }^{9}$

Lenin's most famous writing concerning the question of the socialist state, The State and Revolution, was similar in its argumentation. He defended the 'Marxist' conception of the dictatorship of the proletariat against the liberal ideas of Kautsky:

The theory of the class struggle, applied by Marx to the question of the state and the socialist revolution, leads as a matter of course to the recognition of the political rule of the proletariat, of its dictatorship, i.e. of

8 Lenin 1967g, p. 70.

9 Lenin 1967g, pp. 52, 66. 
undivided power directly backed by the armed force of the people. The overthrow of the bourgeoisie can be achieved only by the proletariat becoming the ruling class, capable of crushing the inevitable and desperate resistance of the bourgeoisie, and of organising all the working and exploited people for the new economic system. The proletariat needs state power, a centralised organisation of force, and organisation of violence, both to crush the resistance of the exploiters and to lead the enormous mass of the population - the peasants, the petty bourgeoisie, and semi-proletarians - in the work of organising a socialist economy. ${ }^{10}$

A real Marxist recognises the necessity of the dictatorship of the proletariat. The proletariat has to crush the repressive state machine, a task that is in the interests of both the working class and the peasants:

On the other hand, he [Marx] stated that the 'smashing' of the state machine was required by the interests of both the workers and the peasants, that it united them, that it placed before them the common task of removing the 'parasite' and of replacing it by something new."1

To Marx, the Paris Commune was the primary example of this 'new organ', taking the place of the old state machine. Once the state machine is substituted by the new organ, a specific power organisation becomes unnecessary. The people recognise the oppressor and can effectively keep it in control. ${ }^{12}$ The process of the withering away of the state can begin. The withering away of the state is also made possible by the simplification of the functions of the state apparatus once its repressive functions become obsolete:

Capitalist culture has created large-scale production, factories, railways, the postal service, telephones, etc., and on this basis the great majority of the functions of the old 'state power' have become so simplified and can be reduced to such exceedingly simple operations of registration, filing and checking that they can be easily performed by every literate person, can quite easily be performed for ordinary 'workmen's wages', and that these functions can (and must) be stripped of every shadow of privilege, of every resemblance of 'official grandeur'.13 
The dying away of the state is a theme that was not discussed in Kautsky's writings even though Lenin did not explicitly criticise him for this neglect. There is not, however, such a great difference between Lenin's and Kautsky's respective conceptions of the future socialist state. According to Kautsky, a centralised state is needed even in socialism for the organisation of production. Lenin's conception was rather similar, as revealed by his characterisation of the future state. In The State and Revolution, the postal service is mentioned as the ideal example of the future socialist state:

To organise the whole economy on the lines of the postal service so that the technicians, foremen and accountants, as well as all officials, shall receive salaries no higher than 'a workman's wage', all under the control and leadership of the armed proletariat - this is our immediate aim. This is the state and this is the economic foundation we need. This is what will bring about the abolition of parliamentarism and the preservation of representative institutions. This is what will rid the labouring classes of the bourgeoisie's prostitution of these institutions. ${ }^{14}$

The metaphor of the postal service was not that different from Kautsky's characterisation of the future state; to Kautsky, as to Lenin, it was the modern industrial factory which had already solved the problems of technical efficiency and planning that functioned as the model of the future state. ${ }^{15}$

There was, however, an important difference between the two conceptions. In The State and Revolution, Lenin's conception of democracy was almost directly opposed to that of Kautsky. According to Lenin, bourgeois democracy is always equal to government by a minority:

In capitalist society, providing it develops under the most favourable conditions, we have a more or less complete democracy in the democratic republic. But this democracy is always hemmed in by the narrow limits set by capitalist exploitation, and consequently always remains, in effect, a democracy for the minority, only for the propertied classes, only for the rich. Freedom in capitalist society always remains about the same as it was in the ancient Greek republics: freedom for the slave owners. Owing to the conditions of capitalist exploitation, the modern wage slaves are so crushed by want and poverty that 'they cannot be bothered with demo-

\footnotetext{
14 Lenin 1967f, p. 304.

15 Kautsky 1910, pp. 112-14.
} 
cracy', 'cannot be bothered with politics'; in the ordinary, peaceful course of events, the majority of the population is debarred from participation in public and political life. ${ }^{16}$

Lenin's understanding of the class character of democracy seemed to be based largely on an analysis of the factual social position of the different classes. Democracy is a formal principle. It does not pay attention to the fact that members of the working class and other poor classes of society are factually deprived of all the means of exercising power, whereas capitalists have all the necessary economic and political means at their disposal; they can even influence the opinions of the people by these means. Kautsky paid scant attention to this fact; to Lenin, democracy is a formal principle, and democratic institutions - a general franchise, free press and freedom of assembly - are really insufficient to guarantee the realisation of the interests of the majority in society. There is, however, one important argument in Kautsky's analysis which was not at all commented on by Lenin: in Kautsky's view, the working class has one important resource of power and influence at its disposal, organisation, and the power represented by an organisation is best increased within democratic institutions. Lenin did not seem to acknowledge that the power of mass organisations would increase in democracy; Kautsky put all his hopes in them. This fact also partly explains Kautsky's 'ultrademocratism'.

Despite the evident differences in their respective analyses, there are in fact some presumptions common to both Lenin and Kautsky. These similar premises are more evident in Lenin's earlier writings about the nature of the future revolution. In 1905, during the first Russian Revolution, Lenin's position was very close to that of Kautsky. The immediate task of the revolution was understood to be the establishment of a democratic state with all the modern democratic institutions. A democratic revolution was thus the immediate task; a socialist one would follow later. In Two Tactics of Social Democracy in the Democratic Revolution, Lenin wrote without reservation:

Whoever wants to reach socialism by any other means than that of political democracy, will inevitably arrive at conclusions that are absurd and reactionary both in the economic and political sense. ${ }^{17}$

\footnotetext{
$16 \quad$ Lenin 1967 f, p. 333 .

17 Lenin 1967 b, p. 468.
} 
Democracy is also necessary for the organisation and development of the consciousness of the proletariat. Lenin's conception was similar to that of Kautsky in another respect: according to both of them, it is mainly the task of the proletariat to realise a bourgeois revolution, because the bourgeoisie is neither willing nor capable of realising this task. A bourgeois revolution is, then, paradoxically more in the interests of the proletariat: 'From this conclusion, among other things, follows the thesis that in a certain sense a bourgeois revolution is more advantageous to the proletariat than to the bourgeoisie. ${ }^{18}$

The development of democracy is, like the general development of capitalism, favourable to the proletariat in general - a proposition regularly found in Kautsky's writings. Lenin had, then, the right to claim that he had always presented the Social Democratic ideas of Kautsky and Bebel. There was not, in fact, any major difference between Lenin's and Kautsky's conceptions at this stage. ${ }^{19}$ Lenin even criticised the idea of 'revolutionary communes' because it did not make any distinction between a democratic and a socialist revolution:

It is, however, precisely for this very reason that the slogan of 'revolutionary communes' is erroneous, because the very mistake made by the communes known to history was that of confusing the democratic revolution with the socialist revolution. On the other hand, our slogan - a revolutionary democratic dictatorship of the proletariat and the peasantry - fully safeguards us against this mistake. While recognising the incontestably bourgeois nature of a revolution incapable of directly overstepping the bounds of a mere democratic revolution our slogan advances this particular revolution and strives to give it forms most advantageous to the proletariat; consequently, it strives to make the utmost of the democratic revolution in order to attain the greatest success in the proletariat's further struggle for socialism. ${ }^{20}$

There is, however, one important difference between Lenin's and Kautsky's opinion. For Kautsky, the difference between a democratic (or more generally,

18 Lenin 1967 b, p. 486.

19 Lenin's bitter reaction to Kautsky's critique of the Russian Revolution becomes understandable when one keeps in mind that to Lenin, as well as to other Bolsheviks, Kautsky had been the main theoretical authority of Social Democracy. In the preface to The Development of Capitalism in Russia, for instance, Lenin referred to Kautsky's Agrarfrage as the most noteworthy contribution to recent economic literature since the publication of the third volume of Capital (Lenin 1963-74a). 
a political) and a social revolution was more one of degree. Socialism and social revolution will automatically follow as soon as Social Democrats have a majority in parliament. Lenin, on the other hand, made a sharp distinction between a democratic and a socialist state and revolution. Before the Russian Revolution, Kautsky continuously defended the idea of the dictatorship of the proletariat against revisionists, but his conception of dictatorship remained devoid of content or was merely equal to the majority rule in parliament. ${ }^{21}$ According to Lenin, the democratic state has to be followed by the dictatorship of the proletariat representing a totally different form of state, and finally, in communism, the state is supposed to wither away.

Many critics have highlighted the apparent contradiction in Lenin's conceptions of 1905 and 1917-18, respectively. The contradiction is a real one, even though Lenin could claim that his idea of the two phases of revolution had remained intact in 1917; the February Revolution was the expected democraticbourgeois revolution, and the October Revolution was the following socialist one. According to Lenin, the development of capitalism had been so rapid in Russia that a socialist revolution could follow the democratic one almost immediately. They both took place within one single year:

Beginning with April 1917, however, long before the October Revolution, that is, long before we assumed power, we publicly declared and explained to the people: the revolution cannot now stop at this stage, for the country has marched forward, capitalism has advanced, ruin has reached fantastic dimensions, which (whether one likes it or not) will demand steps forward, to socialism. For there is no other way of advancing, of saving the war-weary country and of alleviating the sufferings of the working and exploited people. ${ }^{22}$

And further:

It was the Bolsheviks who strictly differentiated between the bourgeoisdemocratic revolution and the socialist revolution: by carrying the former through, they opened the door for the transition to the latter. This was the only policy that was revolutionary and Marxist. ${ }^{23}$

\footnotetext{
21 Lichtheim 1964, p. 269.

22 Lenin 1967g, p. 104.

23 Lenin 1967g, pp. 114-15.
} 
In 1917, there was no longer such a big difference between the two revolutions; they could only be separated by the criterion of the preparedness and willingness of the proletariat:

The attempt to raise an artificial Chinese wall between the first and second, to separate them by anything else than the degree of preparedness of the proletariat and the degree of its unity with the poor peasant, means to distort Marxism dreadfully, to vulgarise it, to substitute liberalism in its place. $^{24}$

In referring to the degree of preparedness of the working class as the decisive criterion for the actuality of revolution, Lenin was arguing along the lines of his previous analysis and following Kautsky's analysis. But it could still be doubted as to whether Lenin had previously meant that the schooling of the proletariat in the class struggle within a democratic state really could be substituted by 'one single revolutionary day' or some months of actual revolutionary struggles.

In addition to the question of democracy and dictatorship, the controversy between Lenin and Kautsky about the Russian Revolution concentrated on the problem of the present stage of development of capitalism - and of Russia in particular. The class structure of different capitalist states was considered to be an essential indicator of the ripening of the conditions for socialism. In the opinion of Kautsky, the majority of the population consisted undoubtedly of the proletariat in all the developed countries, and this fact proved the conditions for socialism to be ripe in those countries. Lenin posed the problem in a similar way. The main question in his analyses, both before and after the Russian Revolution, pertained to the relation of the proletariat to the two other big classes in Russia, the peasants and different factions of the petit bourgeoisie. Even Lenin acknowledged that the proletariat represented only a small minority in Russian society, even though in his early empirical study of the development of capitalism in Russia he had come to the conclusion that the situation of the poor peasant, due to the introduction of capitalistic market relations in the countryside, was starting to resemble more and more the situation of the proletariat. ${ }^{25}$ In Lenin's analysis, small peasants and propertyless farm workers were also the main allies of the proletariat in the coming democratic and socialist revolutions. It was in the interests of these classes to oppose the bour-

24 Lenin 1967g, p. 105.

25 Lenin 1963-74a. 
geois state apparatus which was exploiting the vast majority of the population. The future destiny of revolution was essentially linked with the future of the proletariat, small peasants and farm workers.

Kautsky never acknowledged that the interests of the peasants could be similar to those of the real proletariat or wage workers. Soviet Russia was nothing but a peasant republic [Bauernrepublik], or a form of tartar socialism. In analysing the future tasks of revolution, even Lenin had to admit that the main problem facing the young socialist state was the reaction of the petit bourgeoisie. In his The Tasks of the Proletariat in Our Revolution, written on 10 March 1917, Lenin in fact characterised Russia as the most petit bourgeois country in Europe. The proletariat represented only a negligible part of the population, and both its organisations and socialist consciousness were rather weak. ${ }^{26}$

In 'Left-wing' Communism: An Infantile Disorder, written in 1920, Lenin finally stated that the immediate task of the revolution was the liquidation of all petitbourgeois elements in society. ${ }^{27}$ The petit bourgeoisie is not mainly dangerous and harmful because of its opposition to socialism. The main danger lies in the fact that it continously nourishes capitalistic tendencies in society:

Unfortunately, small-scale production is still widespread in the world, and small-scale production engenders capitalism and the bourgeoisie continuously, daily, hourly, spontaneously, and on a mass scale. All these reasons make the dictatorship of the proletariat necessary, and victory over the bourgeoisie is impossible without a long, stubborn and desperate life-and-death struggle which calls for tenacity, discipline, and a single and inflexible will. ${ }^{28}$

The final abolition of all classes in society is not yet accomplished by destroying capitalists and landlords; all the small-scale producers (or elements of the petit bourgeoisie) must be abolished simultaneously. They cannot, however, simply be destroyed and expurgated; they must be transformed and educated to become different kinds of people. The existence of a petit bourgeoisie is a constant danger to the proletariat and socialism because it constantly nourishes individualism and destroys the necessary discipline of the proletariat. In order to oppose individualism, a proletarian organisation with iron discipline

\footnotetext{
$26 \quad$ Lenin 1967e, p. 27.

27 Lenin 1967 h, p. 339.

28 Ibid.
} 
is needed. The necessity for a centralised and disciplined party as the ideal form of proletarian emancipatory organisation is - even after the illegal phase of the struggle was over - thus deduced by Lenin from the minority position of the proletariat in Russian society; a conclusion which, in Kautsky's opinion, proved the undemocratic and unsocialist character of this revolution. Proletarian dictatorship meant, according to Lenin:

a persistent struggle - bloody and bloodless, violent and peaceful, military and economic, educational and administrative - against the forces and traditions of the old society. The force of habit in millions and tens of millions is a most formidable force. Without a party of iron that has been tempered in the struggle, a party enjoying the confidence of all honest people in the class in question, a party capable of watching and influencing the mood of the masses, such a struggle cannot be waged successfully. It is a thousand times easier to vanquish the centralised big bourgeoisie than to 'vanquish' the millions upon millions of petty proprietors; however, through their ordinary, everyday, imperceptible, elusive and demoralising activities, they produce the very results which the bourgeoisie need and which tend to restore the bourgeoisie. Whoever brings about even the slightest weakening of the iron discipline of the party of the proletariat (especially during its dictatorship), is actually aiding the bourgeoisie against the proletariat. ${ }^{29}$

In this statement, Lenin actually seemed to be acknowledging Kautsky's critique of the Russian Revolution and proletarian dictatorship. If Soviet Russia actually is a petit-bourgeois country, and if socialism can be victorious only by suppressing millions and millions of peasant and small-scale proprietors, Soviet Russia really is shown to be a case of a peasant state or tartar socialism prophesied by Kautsky. The revolution will triumph only at the cost of the majority of the population, the petit bourgeoisie and the peasants, violating their real interests, as acknowledged by Lenin's idea of the necessity for iron discipline inside the party. The interests of the proletariat will be realised only through a disciplined organisation.

For Lenin, the petit bourgeoisie was not, however, the only problem of the socialist revolution. The very core of the proletariat - the organised workers and their immediate interests - posed a serious threat to the party and the proletarian dictatorship. Lenin claimed that even the most organised part of 
the proletariat, represented by the trade unions, had everywhere caused serious splits inside the proletariat and its movement. Trade unions, in fact, only represent specific interests of specific groups of workers, and not the general interest of the proletariat:

The trade unions were a tremendous step forward for the working class in the early days of capitalist development, inasmuch as they marked a transition from the workers' disunity and helplessness to the rudiments of class organisation. When the revolutionary party of the proletariat, the highest form of proletarian class organisation, began to take shape (and the Party will not merit the name until it learns to weld the leaders into one indivisible whole with the class and the masses) the trade unions inevitably began to reveal certain reactionary features, a certain craft narrow-mindedness, a certain tendency to be non-political, a certain inertness, etc. ${ }^{30}$

In the more developed European countries, the reactionary features of trade unions are even more developed. In Russia, trade unions have traditionally been the main supporters of Mensheviks as well. In Western countries, Mensheviks (read: revisionists and reformists) have an even more pronounced position in the trade unions. There is a reactionary faction of trade union workers in the West:

there the craft-union, narrow-minded, selfish, case-hardened, covetous, and pettybourgeois labour-aristocracy, imperialist-minded, and imperialistcorrupted, has developed into a much stronger section than in our country. ${ }^{31}$

Lenin was paradoxically faced with a twofold opposition: both the petit bourgeoisie and peasants (the vast majority in Russia) and the organised and skilled workers (a small but influential minority) oppose the Bolsheviks and their policy. The only supporters of the Bolshevik Party then are the poor unskilled workers.

The reasons given by Lenin for the revisionistic tendencies inside the working class were rather superflous and they closely resembled those analysed by Kautsky. Workers organised in trade unions have certain specific economic

$30 \quad$ Lenin 1967 h, p. 362.

31 Lenin 1967h, p. 363 . 
interests which can be in contradiction with the general political goal of the proletariat as determined by scientific socialism and a proletarian party. The workers' aristocracy, a specific faction of the working class, is able to gain privileges from capitalists, especially during the stage of imperialism: a monopolistic bourgeoisie is able to buy the support of skilled workers and bribe them with economic privileges.

As a conclusion from the above discussion, Lenin stated that it was easier to start a revolution in Russia than in other European countries. On the other hand, in Russia it was much more difficult to complete the revolution. ${ }^{32}$

The threat posed by the petit bourgeoisie in socialism was understood by Lenin to be a strategic problem, namely, how to overcome its opposition and prevent the further development of capitalistic tendencies in Russia. The problem of the revisionistic tendencies within the working class is, however, a more important one. If Lenin's analysis of the possible supporter of the party is correct, then the conflict between the specific economic interests and the general political interests of the proletariat remains unresolved. One would almost naturally expect the oldest and most organised sectors of the proletariat to be the most vehement supporters of socialism, not its opponents. The problem is connected with Lenin's general analysis and conception of the development of the socialist consciousness of the workers. In this respect, Lenin's position was very similar to that of Kautsky. According to both Lenin and Kautsky, the consciousness developing spontaneously among wage workers could only be trade-unionistic. A real socialist consciousness must be brought into the workers' movement from outside:

The history of all countries shows that the working class, exclusively by its own effort, is able to develop only trade union consciousness, i.e., the conviction that it is necessary to combine in unions, fight the employers, and strive to compel the government to pass necessary labour legislation, etc. 33

The principal problem facing Lenin was then the following: if the wage workers can never spontaneously develop a genuine socialist consciousness, and the party is the only representative of a genuine socialist consciousness, where does the socialist idea come from in the last instance? Both Lenin and Kautsky answered the question similarly: the idea and goal of socialism is the result

$32 \quad$ Lenin 1967 h, p. 374.

33 Lenin 1967a, p. 122. 
of scientific socialism, a theoretical knowledge represented by intellectuals. Scientific socialism is a theory of socialist revolution, its necessity and the social conditions leading to it, and only insofar as wage workers are willing to accept the conclusions of scientific socialism as an adequate expression of their own interests and aspirations as wage workers are they qualified to represent the general interests of the proletariat and the final goal of socialism.

As has already been pointed out in analysing imperialism, democracy seems to be either a principle incompatible with or alien to capitalism (Kautsky), or a principle which is only contingent to capitalism and does not have any rooting in the social relations of bourgeois society (Lenin). For both Kautsky and Lenin, the proletariat is the only genuine representative of democracy in capitalism. The bourgeoisie - once an adherent of democracy in its fight against feudalism - has become reactionary and more or less directly represses any democratic aspirations in society. A democratic revolution would then be exclusively in the interests of the proletariat, and it would furthermore lead more or less immediately to a socialist revolution too. In the case of Kautsky, this position is quite evident. For Kautsky, the establishment of democracy would in the end inevitably lead to the establishment of a socialist state. Once the proletariat has become the majority in a society and, consequently, in a parliament too, it would accomplish a socialist revolution using the state institutions at its disposal. A capitalist society having a democratic constitution and a proletarian majority would be, in fact, unable to survive for any length of time. Democracy thus has nothing to do with the social relations of a bourgeois society; it is a pure question of power and the ideal constitution for the proletariat to exercise its power in society. ${ }^{34}$

Lenin continuously accused Kautsky of representing a formal conception of democracy and forgetting the class character of bourgeois democracy. Even though he undersigned Kautsky's idea of democracy as the most suitable training ground for the proletarian organisations and as the best means of organising the working class in his earlier writings, in the writings written after the Russian Revolution, democracy is no longer understood to be relevant to the proletarian struggle. Lenin claimed to be taking into account the factual position of classes in society. In capitalism, the bourgeoisie has all the political and economic means of power at its disposal; consequently, only it can effectively make use of the democratic institutions and exercise its power through them. Parliamentary democracy is only a formal principle which does not pay attention to the factual social position of the different classes in a bourgeois society. 
The proletariat does not possess the factual means to make use of its democratic rights - freedom of the press, general franchise, freedom of assembly even under a democratic constitution. Only the establishment of a dictatorship of the proletariat would deprive the bourgeoisie of its factual political power and establish the genuine political rights of the proletariat. In this sense, the dictatorship of the proletariat, while realising the power and interests of the majority exploited in capitalism, represented to Lenin real and genuine democracy; it is more democratic than the formal bourgeois parliamentary democracy.

To Lenin, then, a state is always essentially an instrument at the disposal of the ruling class - a class possessing the factual economic and political resources of power in society - and in capitalism the state will always represent the interests of its ruling class, the bourgeoisie, notwithstanding its possible democratic constitution. Democracy as such has nothing to do with the bourgeois society, and parliamentary democracy has nothing to do with real democracy. A bourgeois democracy is bourgeois and a proletarian democracy is proletarian, depending on the factual power position of the classes. To Kautsky, democracy simply meant the exercise of the power of a majority in a society, and once the proletariat has become a majority it will be able to exercise its power through a parliament and transform the society into a socialist one. Democracy is thus in the interests of the proletariat; the bourgeoisie represents violence and reaction in society. Either democracy is thus a principle opposed to bourgeois society (Kautsky), or it is a purely formal principle, the class character of which will depend on the factual power position of the classes (Lenin). The main difference between Lenin and Kautsky is that whereas they both agreed that a bourgeois state is always an instrument of power in the hands of its ruling class, the bourgeoisie, Kautsky thought that socialism could only flourish in a society having a democratic constitution and, furthermore, that parliamentary democracy is the ideal form of the future socialist state. Lenin - even though not principally denying the possibility of a socialist revolution using democratic institutions - thought of it more as an exception.

As pointed out by Steenson ${ }^{35}$ and Lichtheim, ${ }^{36}$ Kautsky certainly was a radical democrat by conviction. There is, however, one feature in Kautsky's thinking that makes his strong adherence to parliamentary democracy understandable. Kautsky made a clear distinction between political and social revolution. It was the political revolution which first made possible the further social 
revolution - understood as comprising mainly the socialisation of large-scale production by the state. In analysing the future socialist revolution, Kautsky seemed mainly to be discussing the first political phase of this revolution, which was then often not practically related to the wider social tasks of the ensuing socialist revolution. Furthermore, it was Kautsky's strong reliance on the development of the power of the proletarian organisations which formed the necessary connection between democracy and socialism.

As already noted at the end of the discussion of Kautsky's and Lenin's theories of imperialism, capitalism was understood by the Second International Marxists as being primarily a mode of production based on the exploitation of surplus value and the distribution of the whole national product on behalf of the capitalists. The capital-wage labour relation was basically analysed as a relation of direct exploitation, and the specific character or form of the social relations in a bourgeois society (for example, the relation between equal and free commodity producers, emphasised by Marx) was largely neglected. Similarly, in their analyses, democracy had nothing to do with the specific social relations of commodity producers in capitalism or with the freedom and equality of the commodity exchangers, wage workers included. The conceptions of imperialism represented by these Marxists are a further consequence of this basic understanding of the nature of capitalism. Imperialism was, in fact, understood by both Kautsky and Lenin to be a specific mode of distribution based on the direct appropriation of a part of the national product by big cartel magnates and finance capitalists who are exploiting the rest of the people. Thus freedom and equality are principles which do not even formally belong to an imperialist society. Imperialism, which was explicitly claimed to be violent and reactionary, is based on the appropriation of monopoly profits that do not stem from any relation of production, but rather arise out of a forced distribution of the national - and international - product to the benefit of finance capital. Imperialism is essentially characterised by an accentuating antagonism of distribution.

To the theoreticians of imperialism, capitalism seems to be all but a short historical phase between an earlier mode of production (namely, simple commodity production) and a following mode of production (namely, imperialism). Classical capitalism - capitalism of free competition - was understood as having been transformed into imperialism according to its own economic laws of development, and thus it was only a short interregnum between simple commodity production and imperialism. And if there is any freedom and equality of commodity producers at all, they seem to belong exclusively to the stage of simple commodity production. As soon as the capital relation and wage labourer come into being in society, capitalism inevitably develops towards 
increasing centralisation and monopolisation of production and thus leads to the exploitation of all the producers and consumers in society by centralised finance capital. For the bourgeoisie, then, democracy is only a tactical weapon in its fight against feudalism and absolutism; a capitalism standing on its own is by its nature violent, reactionary and undemocratic. 